\title{
POLA KEMITRAAN DALAM PENGELOLAAN SUMBERDAYA ARKEOLOGI*
}

Sedyawaty, Edy, 2001.

Menuju Arkeologi Maritim Indonesia. Dalam Diskusi Ilmiah Arkeologi

(DIA) XII. Makassar IAAI Komda Sulawesi, Maluku dan Irian. (tt).

Simanjuntak, Truman dkk 2003,

Rencana Induk Penelitian Arkeologi. Jakarta:Pusat Penelitian dan Pengembangan Arkeologi Nasional.

Suantika, I Wayan, 2005.

Menelusuri Kebudayaan Hindu di Kecamatan Kei Besar dan Kei Kecil; Kabupaten Maluku Tenggara; Provinsi Maluku. Ambon: Balai Arkeologi Ambon. (tt).

Sudarmika, IGM, 2001.

Laporan Penelitian Arkeologi, di Pulau Lakor, Kecamatan Leti Moa Lakor, Maluku Tenggara Barat. Ambon: Balai Arkeologi Ambon (tt).

2001.

Laporan Penelitian Arkeologi di Kepulauan Tanimbarkei Kecamatan Tanimbar Utara dan Kecamatan Tanimbar Selatan, Maluku Tenggara Barat. Ambon: Balai Arkeologi Ambon (tt).

Sukendar, Haris, 2001,

Peranan Laut Dalam Perkembangan Budaya Sektor Indonesia Barat, Tengah, Timur dan Pasifik, Dalam Diskusi Ilmiah Arkeologi (DIA) XII. Makassar IAAI Komda Sulawesi, Maluku dan Irian. (tt).

Poelinggomang, E.L, 2001,

Perdagangan Maritim Indonesia Jaringan dan Komoditinya, Dalam Diskusi Ilmiah Arkeologi (DIA) XII. Makassar IAAI Komda Sulawesi, Maluku dan Irian. (tt).
G. M. Sudarmika

\section{Pendahuluan}

Permasalahan arkeologi, baik sebagai ilmu maupun sebagai institusi pemerintah semakin hari semakin kompleks, seiring dengan tuntutan atau keinginan dari pemerintah itu sendiri. Dimana lembaga arkeologi itu harus dapat memberikan kontribusinya yang nyata bagi pengembangan pembangunan bangsa. Sehingga dari waktu ke waktu, tahun ke tahun dan dari program ke program kegiatan kearkeologian terus diselaraskan sesuai dengan tuntutan jaman dan kebijakan pemerintah yang akuntabel. Tentu akan sangat berbeda pandangan antara institusi arkeologi yang ada di luar negeri dengan institusi arkeologi yang ada di Indonesia dalam menyikapi sebuah kegiatan kearkeologian. Kalau mungkin bisa dibandingkan, misalnya institusi di luar negeri kinerjanya selalu di arahkan pada kemajuan ilmu, metode, penelitian murni tapi kalau di Indonesia lebih ditekankan pada manfaat dari hasil kegiatan arkeologi itu sendiri untuk pembangunan bangsa baik sekarang maupun dimasa depan. Dengan kondisi tersebut maka kegiatan kearkeologian di Indonesia pada masa sekarang harus diupayakan untuk dapat berkontribusi aktif dalam mengisi pembangunan.

Gejala ini dibuktikan dengan adanya perubahan-perubahan struktur organisasi arkeologi di tingkat pusat dan daerah. Selain itu pula adanya perubahan nomenklatur yang ada di tingkat eselon dua yaitu Pusat Penelitian dan Pengembangan Arkeologi Nasional. Dengan memaknai nama tersebut maka ada dua hal yang harus disikapi dengan baik yaitu; selain mengadakan penelitian kita harus memikirkan juga pengembangan dari hasil penelitian itu atau kegiatan penelitian itu

* Makalah ini pernah disampaikan dalam Evaluasi Hasil Penelitian Arkeologi pada tahun 2006 yang diselenggarakan oleh Pusat Penelitian Arkeologi Nasional

Kapata Arkeologi Vol. 4 Nomor 7 / November 2008 
yang dikembangkan. Yang menjadi permasalahan sekarang adalah jelas yaitu istilah pengembangan dalam sebuah lembaga penelitian, sehingga timbul pertanyaan, apa yang dikembangkan dan bagaimana mengembangkannya sehingga hasil dari pengembangan itu sesuai dengan kebijakan pemerintah. Maka untuk menanggapi hal tersebut mungkin salah satunya adalah dengan cara mengembangkan pola kemitraan dalam pengeloaan sumberdaya arkeologi, yaitu mulai dari penelitian, pemanfaatan dan pelestariannya, hal ini sesuai dengan program dari DIPA arkeologi tahun 2006 yaitu program kemitraan. Sebuah kerangka penelitian harus juga disertakan upaya pemanfaatannya dan pelestariannya, sehingga kegiatan sebuah lembaga arkeologi tidak mentok sampai ditingkat penelitian. Istilah pemanfaatan dan pelestarian di dunia penelitian arkeologi mungkin terasa aneh, tapi sebenarnya itu adalah pemikiran maju sehingga hasil-hasil dari penelitian itu dapat dimanfaatkan/dinikmati oleh masyarakat banyak bukan arkeologi untuk arkeologi. Kemitraan yang perlu dikembangkan dalam hal ini adalah bagaimana kita mencari teman untuk bersama-sama mengelola tinggalan arkeologi itu, sehingga dengan pola ini diharapkan hasil-hasil penelitian itu dapat dikembangkan menjadi suatu produk yang berguna bagi masyarakat sekitar situs khususnya, maupun bangsa dan Negara pada umumnya.

\section{Kemitraan Dalam Pengelolaan Sumberdaya Arkeologi}

\subsection{Kemitraan Dalam Pengembangan Kegiatan Penelitian}

Dalam sebuah lembaga penelitian arkeologi pengelolaan tinggalan arkeologi kegiatannya akan lebih mentitikberatkan pada upaya-upaya atau bentuk kegiatan penelitian sesuai dengan metode penelitian arkeologi. Artinya dalam keadaan bagaimanapun teknis penelitian arkeologi harus tetap memakai kaidah/aturan atau metode penelitian arkeologi yang sudah baku. Penelitian arkeologi yang berpola kemitraan disini dapat melibatkan pihak terkait sebagai peninjau dalam sebuah kegiatan penelitian, pihak terkait misalnya BP3, Dinas Kebudayaan, Dinas Pariwisata, dan Pemerintah Desa, dengan melibatkan mereka itu kita akan lebih mudah dalam pengembangannya. Memang tidak semua situs atau data arkeologi dalam penelitiaannya melibatkan institusi tersebut di atas. Kita harus mampu memprediksi terhadap situs yang akan kita teliti. Memprediksi situs dalam hal ini dapat berupa a.1 ; lokasi situs, jenis situs dan sifat situs. Misalnya situ-situs yang bisa dikembangkan sebagai obyek pariwisata kita melibatkan Pemda dan Dinas Pariwisata. Situs yang membutuhkan upaya pelestarian kita libatkan Pemda dan BP3, sehingga pelibatan dari suatu instansi dilihat dari prospek situs itu sendiri. Kemudian masyarakat di dekat situs harus dilibatkan secara aktif dalam setiap kegiatan penelitian. Tidak saja pada saat berlangsungnya suatu kegiatan penelitian, yang lebih penting lagi adalah bahwa tim penelitian harus dapat memberikan/mendistribusikan hasil penelitian itu secepatnya pada masyarakat sekitarnya. Artinya apapun hasilnya dalam penelitian tersebut masyarakat harus segera mengetahuinya, yaitu dengan mengadakan dialog terbatas dengan mengumpulkan tokoh-tokoh masyarakat yang ada disekitarnya dan menyampaikan hasil-hasil dari sebuah kegiatan penelitian yang telah dilakukan itu. Dalam hal ini akan terjadi dua arus timbal balik yang saling menguntungkan yaitu disatu sisi sebagai masukan/tambahan informasi dalam penyusunan laporan dan sisi lainnya masyarakat disekitarnya akan segera dapat memahami tinggalan budaya leluhur dengan baik dan benar, sehingga akan lebih mudah dalam pelestariannya. Karena masyarakat yang sudah mengenal, mengerti dan faham terhadap eksistensi terhadap sebuah tinggalan budaya masa lampau tentu akan merasa perlu untuk memelihara, menjaga dan mengamankannya.

\subsection{Kemitraan Dalam Pengembangan Hasil Penelitian}

Hasil-hasil penelitian yang telah diperoleh di lapangan tersebut tidak akan berhenti setelah laporan penelitian itu diselesaikan. Hasil dari kegiatan penelitian itu harus segera ditindaklanjuti ke arah pengembangannya. Pengembangan hasil penelitian arkeologi itu tidak saja dapat berupa pengembangan ekonomik tapi juga pengembangan idealogik Pengembangan ekonomik dapat diartikan bahwa tinggalan arkeologi tersebut dapat dimanfaatkan sebagai produk pariwisata dan pengembangan idealogik dapat berupa pengembangan nilai budaya leluhur, pemahaman akan akar budaya dan penemuan identitas/jati diri. Pengembangan dalam pemanfaatan ekonomi tentunya kita harus bermitra dengan Pemda dalam hal ini Dinas Pariwisata dan dengan

Kapata Arkeologi Vol. 4 Nomor 7 / November 2008 
BP3 dalam upaya pelestariannya. Sehingga istilah hulu dan hilir yang pernah dikembangkan dalam penanganan tinggalan arkeologi pada masa yang lalu itu kita rintis lagi. Data dari Balai Arkeologi yang berupa hasil dari sebuh kegiatan penelitian (sebagai kegiatan hulu) dapat dilanjutkan/ditindaklanjuti oleh BP3 (sebagai kegiatan hilir) untuk dipugar/direhabilitasi dan kemudian (seandainya memungkinkan) dipromosikan dan dipelihara oleh Dinas Pariwisata sebagai produk pariwisata yang dapat menghasilkan devisa bagi Negara. Sehingga proses penangan terhadap tinggalan arkeologi itu dapat ditangani dari awal sampai tuntas (tidak berakhir ditengah jalan).

Tentunya dalam bermitra kerja ini setiap instansi mempunyai batas-batas wewenang dan tanggung jawab yang jelas dalam pelaksanaan tugas pokok dan fungsinya. Pengembangan tinggalan arkeologi sampai pada pelestarian dan pemanfaatannya instansi Balai Arkeologi berfungsi sebatas menghasilkan sebuah kesepakatan kerjasama atau penyatuan sebuah persepsi dalam upaya penanganan Benda Cagar Budaya. Artinya Balai Arkeologi tidak bias turun langsung secara mandiri dalam kegiatan pemugaran/rehabilitasi dan pemanfaatan dari sebuah tinggalan arkeologi. Kegiatan kemitraan lain yang perlu dikembangkan adalah berupa pemberian sumbangan dana cuma-cuma kepada daerah-daerah tempat penelitian yang dianggarkan secara permanen dalam DIPA (terutama desa yang masuk dalam katagori desa miskin). Kemitraan ini merupakan suatu timbal balik nyata dari sebuah kegiatan penelitian, dimana masyarakat sudah dengan rela membantu kita dalam setiap pelaksanaan kegiatan, sehingga kegiatan penelitian dapat berjalan dengan baik. Dana itu diharapkan sebagai rangsangan untuk membangun sarana desa setempat baik yang berhubungan dengan situs/suberdaya arkeologi maupun tidak, sehingga meskipun jumlahnya kecil tapi manfaat dari kegiatan penelitian arkeologi itu dapat dirasakan dalam bentuk lain (attantion participant) oleh masyarakat setempat..

\subsection{Kemitraan Dalam Sosialisasi Hasil Penelitian}

Hasil-hasil penelitian yang telah terhimpun dalam sebuah laporan penelitiaan harus didistribusikan atau disosialisasikan keseluruh lapisan masyarakat. Kegiatan sosialisasi adalah merupakan kegiatan pokok yang harus dimiliki oleh Balai Arkeologi di seluruh Indonesia, karena kegiatan ini disamping sebagai publikasi hasil penelitian juga merupakan pertanggungjawaban atau akuntabilitas terhadap penggunaan anggaran yang notabenanya berasal dari uang rakyat. Kegiatan sosialisasi ini pada masa sekarang harus sudah merupakan kegiatan pokok fungsional setelah kegiatan penelitian. Artinya, misalnya bobot kegiatan ini (sosialisasi) pada masa lalu hanya sekitar $10 \%$ dari total anggaran, maka pada masa sekarang ini harus ditingkatkan menjadi $25 \%$ untuk kegiatan sosialisasi, $35 \%$ penelitian dan $25 \%$ administrasi (kepegawaian/perkantoran) dll. $5 \%$, sehingga eksistensi Balai Arkeologi semakin dikenal dan diperhitungkan. Kegiatan sosialisasi tersebut harus dirancang atau ditata dengan baik sehingga maksud dan tujuan dari sosialisasi itu dapat tercapai secara maksimal. Untuk meningkatkan hasil yang dicapai dalam kegiatan sosialisasi tersebut harus menjalin hubungan dan kerjasama dengan pihak terkait sesuai dengan arah dan tujuan dari kegiatan sosialisasi tersebut, sehingga pola kemitraan dalam hal ini harus dikembangkan dengan baik. Ada beberapa bentuk kegiatan sosialisasi dalam bentuk kemitraan yang cukup efektif yaitu :

1. Sosialisasi dalam bentuk penyuluhan disekolah-sekolah. Dalam kegiatan ini kita harus melibatkan atau bermitra dengan instansi pendidikan yaitu sekolah mulai dari tingkat SMP, SMA dan Perguruan Tinggi;

2. Diskusi Budaya secara luas, kegiatan ini harus melibatkan atau bermitra dengan Pemerintah Daerah (Pemprov, Pemkab/kota, kecamatan dan desa) dan semua unsur masyarakat, misalnya tokoh pemuda, tokoh masyarakat, organisasi pemuda, perguruan tinggi, lembaga kebudayaan non-pemerintah atau LSM Kebudayaan, instansi kebudayaan, pemerhati budaya dan elemen-elemen lainnya yang ada dalam masyarakat;

3. Pameran, kegiatan ini juga harus dapat diikuti oleh seluruh lapisan masyarakt;

4. Lomba karya tulis ilmiah arkeologi, kegiatan ini dapat dikhususkan kepada anak-anak sekolah dalam bentuk kelompok kerja;

5. Simulasi Arkeologi, pelaksanaan kegiatan ini dapat dikemas 
dalam bentuk kegiatan kepramukaan yang melibatkan anakanak sekolah (kemah di situs arkeologi);

6. Kunjungan ke situs-situs arkeologi yang telah diteliti;

7. Penerbitan buku dan liflet yang disebarkan ke instansi terkait secara luas, mulai dari Pemprov, Pemkab/kota, Kecamatan, Pemerinah Desa dan organisasi-organisasi lainnya;

8. Memperluas kerjasama dalam hal penanganan Benda Cagar Budaya.

\section{Penutup}

Pengembangan paradigma lembaga penelitian di bidang arkeologi terus mengalami perubahan dari waktu kewaktu. Kondisi ini terjadi tidak lepas dari arah kebijakan pemerintah dalam memandang sebuah lembaga penelitian khususnya arkeologi, dimana lembaga ini diharapkan dapat memberikan sumbangan yang nyata dalam pembangunan bangsa khususnya di bidang kebudayaan dan pariwisata. Pengembangan paradigma ini sangat dirasakan pada masa reformasi ini, terutama dengan adanya perubahan struktur organisasi pada tingkat pusat. Seiring dengan perubahan tersebut terjadi pula perubahan arah atau orientasi program penelitian mulai dari arkeologi murni, pengelolaan keragaman budaya dan pada masa sekarang lembaga penelitian arkeologi berada pada program kemitraan.

Kemitraan dalam kaitannya dengan pelaksanaan kearkeologian kedengarannya baru tapi pada dasarnya kegiatan kearkeologian sudah lama melibatkan pihak lain baik dalam siklus kepemerintahan maupun di luar pemerintah dan juga dari segi aspek keilmuan. Tapi kemitraan yang selama ini dikembangkan masih mengacu pada satu orientasi yaitu penelitian arkeologi murni. Untuk itu pada masa sekarang pola kemitraan tersebut harus dikembangkan dari penelitian, pengembangan, publikasi dan sampai pada pemanfaatannya.

Pola kemitraan itu harus dirancang secara luas sehingga dapat menghimpun semua unsur kekuatan yang ada baik pusat maupun daerah serta kelompok-kelompok masyarakat, baik masyarakat modern maupun tradisional. Dengan adanya pola kemitraan yang terjalin dengan baik ini diharapkan lembaga penelitian arkeologi dapat memberikan sumbangan yang nyata dalam pembangunan bangsa dan negara. Sebuah lembaga penelitian dapat diakui keberadaannya apa bila hasil-hasil kegiatannya itu dapat memberikan pengetahuan yang baru atau nilai tambah terhadap masyarakat sekitarnya. Sehingga sebuah lembaga penelitian tidak berkutat di dalam lingkarannya sendiri. Untuk itu Balai Arkeologi perlu mencari teman atau bermitra dalam pengeloaan sumberdaya arkeologi terutama dalam pengembangan dan pemanfaatanya.

Secara ringkas ada tiga pola pengembangan kemitraan yang kiranya dapat dibangun dalam penanganan sumberdaya budaya dalam hal ini sumberdaya arkeologi yaitu :

1. Kemitraan dalam pengembangan penelitian;

Yaitu bagaimana mengemas sebuah kegiatan penelitian sehingga dapat melibatkan banyak unsur didalam pelaksanaannya

2. Kemitraan dalam pengembangan hasil penelitian;

Yaitu suatu upaya bahwa hasil-hasil penelitian tersebut dapat dikembangkan sehingga berguna bagi masyarakat sekitar situs, bangsa dan Negara.

3. Kemitraan dalam sosialisasi hasil penelitian

Yaitu suatu upaya untuk menyebarluaskan hasil-hasil penelitian keseluruh lapisan masyarakat dengan hasil yang maksimal dan terukur. 


\section{DAFTAR PUSTAKA}

Sudarmika G.M. 2005

Sumberdaya Arkeologi: Pemanfaatan dan Upaya Pengelolaannya dalam Kapata Vol 1 No 1 Agustus 2005, Balai Arkeologi Ambon, Ambon.

I Wayan Suantika, 2005

Visi dan Misi Balai Arkeologi Ambon, dalam Kapata Vol 1 No 1 Agustus 2005, Balai Arkeologi Ambon, Ambon

Truman Simajuntak dkk, 2003

Rencana Induk Pusat Penelitian Arkeologi, Badan Pengembangan

Kebudayaan dan Pariwisata, Deputi Bidang Plesetarian dan Pengembangan Budaya, Pusat Penelitian Arkeologi, Jakarta, 2003
ARKEOLOGI KOMUNITAS :

Pengelolaan Informasi dan Pengembangan Penelitian

Arkeologi di Indonesia

(Sebuah Pendekatan untuk Wilayah Penelitian di Maluku)*

Wuri Handoko

\section{A. Pendahuluan}

Penelitian arkeologi tak bisa dipisahkan dari masyarakat. Hal ini karena sumberdaya arkeologi baik situs maupun tinggalan arkeologi pada umumnya ditemukan justru di sekitar wilayah hunian masyarakat. Bahkan sebagian besar sumberdaya arkeologi ditemukan di lingkup wilayah masyarakat yang terkecil seperti dusun dan desa. Sumberdaya arkeologi tersebut tak jarang masih memiliki korelasi dengan sejarah dan budaya masyarakat setempat yang masih memiliki ciri lokal atau mempertahankan tradisi dan norma-norma adat yang diwarisi dari leluhurnya. Masyarkat atau komunitas justru dan lebih mengetahui keberadaan sumberdaya arkeologi tersebut, sebelum kehadiran peneliti arkeologi. Selain itu masyarakat juga mengetahui latarbelakang keberadaan sumberdaya arkeologi yang ada berdasarkan pengetahuannya. Maka, tak jarang masyarakat sangat mensakralkan sumberdaya arkeologi tersebut. Selain karena maih berhubungan dengan sejarah dan budaya leluhurnya, juga mereka percaya bahwa sumberdaya arkeologi itut diwariskan oleh para leluhurnya.

Oleh karena itu, berdasarkan tradisi tutur seringkali keberadaan sumberdaya arkeologi juga menjadi sumber informasi bagi pengetahuan masyarakat terhadap sejarah dan kebudayaannya. Dengan demikian jelas, sumberdaya arkeologi tidak saja monopoli bagi arkeologi untuk memperoleh pengetahuan masa lalu. Maka benar, sumberdaya arkeologi adalah milik masyarakat luas selaku generasi penerus sehingga pengetahuan masa lalu tidak saja pengetahuan bagi arkeologi tetapi juga hak azasi setiap manusia (Cleere, 1989, Layton 1989 dan Gimsey 1972).

* Makalah ini pernah disampaikan dalam Evaluasi Hasil Penelitian Arkeologi pada tahun 2006 yan diselenggarakan oleh Pusat Penelitian Arkeologi Nasional

Kapata Arkeologi Vol. 4 Nomor 7 / November 2008 